\title{
The Influence of Promotion and Waqf Knowledge toward Cash Waqf Awareness in Pahang Region
}

Surita Hartini Mat Hassan, Ramlan Mustapha, Maziah Mahmud, Siti Norma Aisyah Malkan \& Nurul Hidayah Che Hassan

To Link this Article: http://dx.doi.org/10.6007/IJARBSS/v11-i4/9816

DOI:10.6007/IJARBSS/v11-i4/9816

Received: 23 February 2021, Revised: 25 March 2021, Accepted: 16 April 2021

Published Online: 29 April 2021

In-Text Citation: (Hassan et al., 2021)

To Cite this Article: Hassan, S. H. M., Mustapha, R., Mahmud, M., Malkan, S. N. A., \& Hassan, N. H. C. (2021). The Influence of Promotion and Waqf Knowledge toward Cash Waqf Awareness in Pahang Region. International Journal of Academic Research in Business and Social Sciences, 11(4), 1252-1260.

Copyright: (c) 2021 The Author(s)

Published by Human Resource Management Academic Research Society (www.hrmars.com)

This article is published under the Creative Commons Attribution (CC BY 4.0) license. Anyone may reproduce, distribute, translate and create derivative works of this article (for both commercial and non-commercial purposes), subject to full attribution to the original publication and authors. The full terms of this license may be seen at: http://creativecommons.org/licences/by/4.0/legalcode

Vol. 11, No. 4, 2021, Pg. 1252 - 1260

Full Terms \& Conditions of access and use can be found at http://hrmars.com/index.php/pages/detail/publication-ethics 


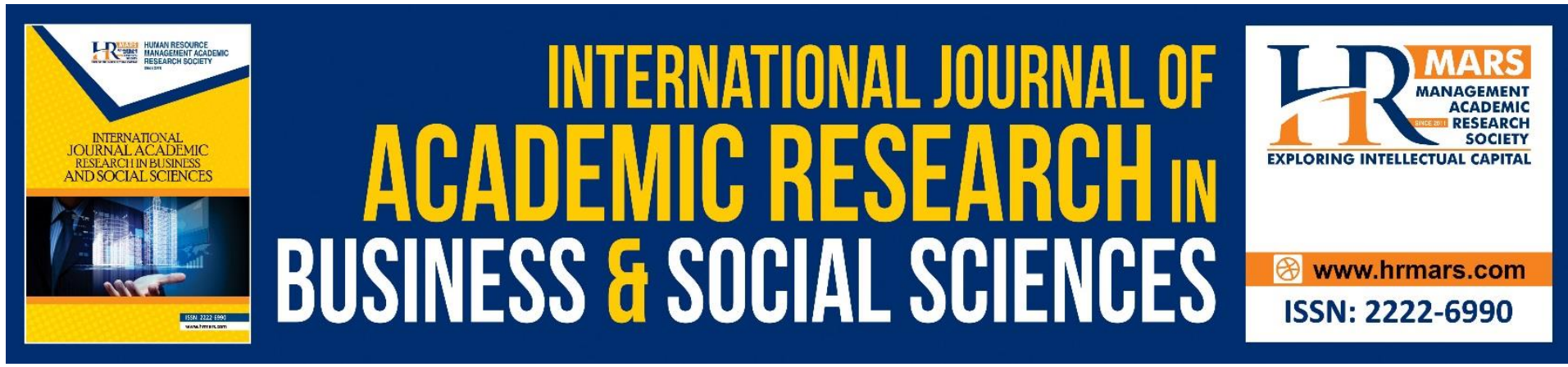

\title{
The Influence of Promotion and Waqf Knowledge toward Cash Waqf Awareness in Pahang Region
}

\author{
Surita Hartini Mat Hassan, Ramlan Mustapha, Maziah \\ Mahmud, Siti Norma Aisyah Malkan \& Nurul Hidayah Che \\ Hassan \\ Universiti Teknologi MARA Pahang, Raub Campus, Malaysia \\ Email: suritahartini@uitm.edu.my
}

\begin{abstract}
The notion that waqf only involves permanent property such as graveyards, mosques and buildings is well established among the community. However, developments during the implementation of wakaf have given birth to new mechanisms involving the use of non permanent property such as money better known as cash wakaf. Cash waqf is a waqf mechanism that raises waqf funds and then converts them into permanent property. However, the existence of this cash wakaf is still in doubt among the community because the use of money is said to be depleted when used. Against the background of this phenomenon, this study was conducted to identify the perception and level of public awareness on the implementation of cash endowment. Accordingly, this study looks at the extent to which the medium of promotion and knowledge gives awareness to the community to implement the cash endowment. This study uses quantitative methods. This study was conducted by distributing questionnaires online using google form to 230 Muslim communities in Pahang region. The data obtained were then analysed using SmartPLS (Structural Equation Modeling). The results of the study found that the factors of promotion and knowledge are significant and positively related in providing awareness and understanding of cash endowment. Although the Muslim community in Pahang region knows and understands about cash wakaf, but the majority still do not get involved in the cash wakaf. It is hoped that this study can help the parties involved, especially MAIN in raising awareness of the local community in order to increase participation in the cash endowment activities that can be participated by all levels of society.
\end{abstract}

Keywords: Awareness, Cash Waqf, Pahang, Promotion

\section{Introduction}

Waqf is an Arabic word which means to withhold (al-Jurjani, 2004: 212; Ibn Manzur, p. 359). It means to withhold 'ain owned by the waqif (waqif) and giving away the benefits. Waqf is a type of sunnah that Muslims are encouraged to practise. Its aim is to draw closer to Allah SWT by contributing a portion of one's wealth to the good of all humanity. Waqf assets, such as land, houses, and money, can produce multiplied income if they are well managed. This is demonstrated by the Ottoman tradition of waqf, which succeeded in relieving the 
government's burden of providing funding sources for construction, education, health, agriculture, and other community needs at the time (Othman, 2012).

Waqf is an Arabic word derived from the root word Waqfa, which means "to keep" or "to detain". Waqf, in its most basic form, is the transition of land ownership to Allah. Cash Waqf is the process of raising funds from donors on a long-term basis and investing them in productive assets that provide usufruct or income. This benefit should be put into future purchases (Nasiri, Noori \& Salleh, 2019). Waqf is a voluntary act of charity for the benefit of Allah that is not considered obligatory. Waqf is a charitable act that is viewed in Islam as a spiritual discipline, a purification of the soul, and assistance to fellow human beings (Amirul et al., 2012). As a result, it is strongly promoted in Islam because it can directly lead to economic growth and the social well-being of Muslims. Waqf is a charitable property donated by the Muslim community. Waqf is unique in that it has enduring, inalienable, and irrevocable characteristics (Hasan and Sulaiman, 2016; Ghazali et al., 2019). The owner's goal in donating is to receive benefits from God in the afterlife (Kahf, 2003; Shabbir, 2018; Faturohman et al., 2020; Hasan et al., 2018). Waqf elements may be moved around.

Waqf is a process in which a property is transferred from human ownership to Allah SWT ownership. The benefits of property will be dedicated to the benefit of Muslims for welfare purposes in this case. In order to preserve the main principle of waqf, as example that it is in an eternal state, waqf should be made up of immovable property such as land and buildings. Based on this eternity, waqf property is carried out on non-transferable property such as land because it will not be damaged or destroyed. This choice is based on the actions of the Prophet (SAW) and his companions, who made this eternal treasure their mawquf object. Furthermore, there are some events that show that during the Prophet (SAW) time, no property was claimed except for land and buildings. According to the scenario, some fuqaha require that a waqf property be of eternal nature and capable of benefiting the public.

In aspects of movable property control, the fuqaha basically decided that their possessions were invalid because they lacked a permanent nature. Because it is vulnerable to damage and change, it is difficult to ensure that this moving property remains eternal to the end. Fuqaha who adhere to the concept of public benefit, on the other hand, accept any form of property to be used as a waqf property. As a result, cash waqf, which is waqf that uses money instruments and is also intended to benefit the public, is included in the form of waqf property. This definition includes all liquidity or cash in other forms, such as company shares.

Waqf is a charitable property donated by the Muslim community. Waqf is unique in that it has enduring, inalienable, and irrevocable characteristics (Hasan and Sulaiman, 2016; Ghazali et al., 2019). The owner's goal in donating is to receive benefits from God in the afterlife (Kahf, 2003; Shabbir, 2018; Faturohman et al., 2020; Hasan et al., 2018). Waqf elements may be moved around.

\section{Cash Waqf in Malaysia}

Techniques for giving and receiving endowments have evolved in tandem with technological advancements and the passage of time. Cash waqf is the type of waqf that is currently being developed. Cash waqf is money paid directly to the institution receiving the waqf. In practice, cash waqf receipt can be accomplished by giving money to Nazir immediately or directly. The cash waqf has made it easier for Muslims to perform the waqf without having to own a suitable plot of land or a specific building that can be used for waqf for the ummah's benefit. Muslims are permitted to do waqf in any way, including through channels or responsible parties, if the value of the money exceeds a certain amount. 
Historically, the Waqf mechanism only permitted the involvement of immovable property or real estate such as a building or land. Unfortunately, it resulted in management issues with unproductive Waqf property and insufficient Waqf funds, resulting in a 'Asset Rich Cash Poor' scenario. In Malaysia, these issues have become the primary focus of discussions among industry practitioners and academics. Fortunately, the Malaysian Fatwa Council endorsed the use of movable property as a Waqf asset, specifically cash, in 2007, which has partially resolved these issues (Khamis \& Salleh, 2018).

Malaysia has taken the initiative to expand the benefits of cash Waqf by establishing the Department of Awqaf, Zakat, and Hajj (JAWHAR) with the goal of standardising cash Waqf management. Dato' Seri Abdullah bin Md Zin, a former Minister in the Prime Minister's Department responsible for Islamic affairs, completed the official launch on October 8, 2004 at the Putrajaya International Convention Centre (PICC).

As a result, JAWHAR has recommended that each SIRC organise several cash Waqf initiatives. First, the SIRC shall open a cash Waqf trust account in any Islamic banking institution. Second, through salary deduction, in which SIRC will assist public and private sector employees in participating by obtaining the Salary Deduction Code from Malaysia's Accountant General's Department. Second, through salary deduction, where SIRC will assist public and private servants in participating by obtaining the Salary Deduction Code from Malaysia's Accountant General's Department, State Treasurer, and Manpower Department approval for public, civil, and private servants, respectively. Third, SIRC must obtain permission from the Inland Revenue Board of Malaysia or the Ministry of Finance to grant tax exemption to those who make cash contributions to Waqf. Fourth, SIRCs are encouraged to work with Islamic financial institutions to increase public participation through banking services such as internet banking, standing orders, and cash deposit machines (Khamis \& Salleh, 2018).

Amirul et al (2012) investigated the factors that influence cash Waqf giving in Malaysia, focusing on religious satisfaction, Waqf literacy, trustworthiness, demographic factors, efficient management, and tax incentives. Via exploratory research, the report aims to gain a clear understanding of the future growth of cash Waqf in Malaysia. According to the findings, religious satisfaction has an impact on cash Waqf giving as a source of intrinsic motivation, as well as confidence in Waqf administration and management. The authors stressed the importance of Waqf literacy, stating that a lack of literacy among the general public contributes to ineffective cash Waqf raising as well as a limited understanding of Waqf diversity.

Several studies have been conducted on the use of cash waqf for business financing (Cizakca, 2004; Elgari, 2004; Dusuki 2008; Hassan, 2010). Elgari (2004) proposed incorporating waqf into the concept of qar asan to provide a source of financing for the poor who are unable to access external finance (interest-free loan). According to the Tohirin (2010), in his studies discovered that cash waqf can help Indonesian SMEs gain access to formal banking institutions. SMEs would be able to expand their business ventures through collaboration with cash waqf institutions if cash waqf assets were used and invested properly (CWIs).

Adeyemi, Ismail and Hassan (2016) attempted to investigate the factors that influence cash Waqf awareness in Malaysia. As a result, the primary goal of this study is to empirically assess Malaysian Muslims' awareness of cash Waqf. According to the empirical evidence, Malaysian Muslims are still unaware of the existence of cash Waqf. The findings also supported the notion that low awareness is caused by a variety of factors. The findings also supported the notion that low awareness is caused by factors such as a lack of understanding, a lack of promotion, and the influence of social culture. 
Mardziyah (2014) investigated the factors influencing online Waqf acceptance in Islamic banking institutions. The objectives of this study were archived using statistical methods such as the Independent Samples T-Test, Analysis of Variance (ANOVA), Pearson Correlation, and Multiple Linear Regression analysis. The findings indicated that four variables are positively correlated with the acceptance of online Waqf at 95 percent and 99 percent confidence levels. According to the research, three factors significantly influence the acceptance of online Waqf, which are perceived usefulness, perceived ease of use, and the amount of information found in. However, perceived religiosity and perceived self-efficacy are found to be insignificant factors influencing the acceptance of online Waqf in Islamic banking institutions.

\section{Methodology}

The quantitative method for data collection is used in this study. When data is collected and analytically processed, the quantitative method is used. Data is numerically coded and statistical results are produced (Lekvall \& Wahlbin, 2001). The quantitative method is suitable if the sample data need to be generalized and applied to the population to find patterns and trends (Davidsson \& Patel, 2003). Data were collected from an automatically administered questionnaire to analyze this study. The questionnaires were distributed in hard copy to all respondents.

\section{Sample}

The research sample in this study consists of 230 Pahang citizens in Malaysia. This study utilized convenience sampling, as the sampling frame was not obtained. According to Sekaran (2003), it is possible to use this method to obtain an initial overview of the situation or to obtain the sampling frame from the researcher. Convenience sampling can be used if the researcher cannot obtain a sampling panel (Malhotra, 2010; Sekaran \& Bougie 2010), although some say it could be biased opinion and does not (represent) the population. This method was selected on the basis of its appropriateness and ease of feedback.

\section{Analysys and Discussion \\ Finding}

Demographic analysis

The demographic information of respondents $(N=290)$ is shown in Table 1 . About $39 \%$ $(\mathrm{N}=110)$ of respondents were male and $61 \%(\mathrm{~N}=180)$ were female. Meanwhile the level of education shown about $94.5 \%$ were high education level and $5.5 \%$ were low education level. Table 1: Demographic data

\begin{tabular}{ccc}
\hline Gender & Range/category & percent \\
\hline Male & 110 & \\
Female & 180 & \\
\hline High education level & Level of education & $94.5 \%$ \\
\hline Low education level & & $5.5 \%$ \\
\hline
\end{tabular}

\section{Measurement Model}

We used partial least squares (PLS) modelling using the SmartPLS 3.2.8 version (Ringle et al., 2005) as the statistical tool to examine the measurement and structural model as it does not require normality assumption and survey research is normally not normally distributed (Chin et al., 2003). 
We followed the suggestions of Anderson and Gerbing (1988) to test the model developed using a 2-step approach. First, we tested the measurement model to test the validity and reliability of the instruments used following the guidelines of Hair et al. (2019) and Ramayah et al. (2018) then we ran the structural model to test the hypothesis developed. For the measurement model we assessed the loadings, average variance extracted (AVE) and the composite reliability (CR). The values of loadings should be $\geq 0.5$, the AVE should be $\geq 0.5$ and the $C R$ should be $\geq 0.7$. As shown in Table 2, the AVEs are all higher than 0.5 and the CRs are all higher than 0.7 . The loadings were also acceptable with only one or two loadings less than 0.708 (Hair et el., 2019).

Table 2 : Measurement model

\begin{tabular}{llccc}
\hline Construct & Item & Loading & CR & AVE \\
\hline \multirow{4}{*}{ Waqf awareness } & INT1 & 0.842 & & \\
& INT2 & 0.434 & 0.838 & 0.578 \\
& INT3 & 0.876 & & \\
& INT4 & 0.804 & & \\
Knowledge & KNOW1 & 0.912 & & 0.521 \\
& KNOW2 & 0.473 & 0.806 & \\
& KNOW3 & 0.755 & & \\
Promotion & KNOW4 & 0.678 & & \\
& PROM1 & 0.824 & & \\
& PROM2 & 0.848 & & \\
& PROM3 & 0.703 & 0.857 & \\
\hline
\end{tabular}

Then in step 2, we assessed the discriminant validity using the HTMT criterion suggested by Henseler et al. (2015) and updated by Franke and Sarstedt (2019). The HTMT values should be $\leq 0.85$ the stricter criterion and the mode lenient criterion is it should be $\leq 0.90$. As shown in Table 4, the values of HTMT were all lower than the stricter criterion of $\leq 0.85$ as such we can conclude that the respondents understood that the 9 constructs are distinct. Taken together both these validity test has shown that the measurement items are both valid and reliable. See table 3:

Table 3: Discriminant Validity (HTMT)

\begin{tabular}{|c|c|c|c|}
\hline & INT & KNOWD & PROM1 \\
\hline \multicolumn{4}{|l|}{ INT } \\
\hline KNOWD & 0.281 & & \\
\hline PROM1 & 0.511 & 0.48 & \\
\hline
\end{tabular}




\section{Structural Model}

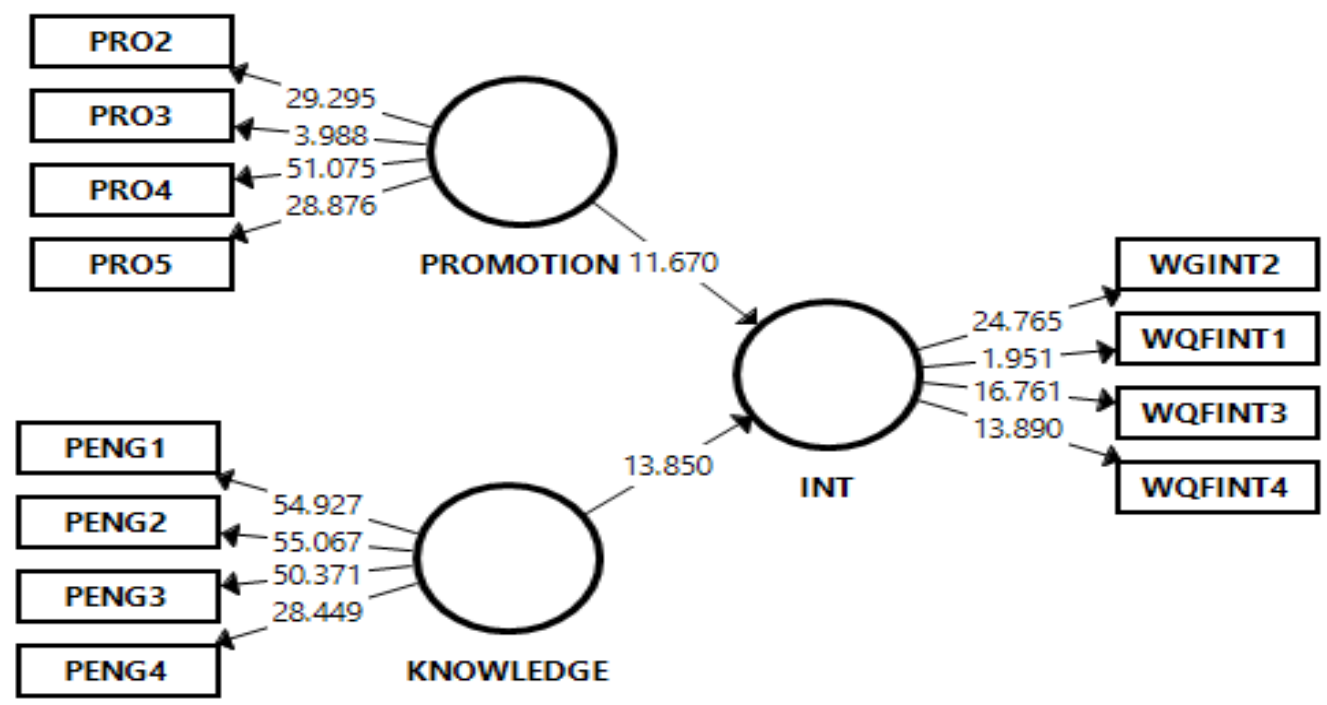

Figure 1: Path coefficient

Table 4: Hypothesis testing

\begin{tabular}{cccccc}
\hline & Standard beta & $\begin{array}{c}\text { Sample } \\
\text { Mean (M) }\end{array}$ & STDEV & T Statistics & P Values \\
\hline $\begin{array}{c}\text { KNOWLEDGE }-> \\
\text { WAQF }\end{array}$ & 0.474 & 0.474 & 0.034 & 13.85 & 0.000 \\
$\begin{array}{c}\text { PROMOTION -> } \\
\text { WQF }\end{array}$ & -0.433 & -0.435 & 0.037 & 11.67 & 0.000 \\
\hline
\end{tabular}

Note: We use $95 \%$ confidence interval with a bootstrapping of 5,000

Figure 1 and Table 3 reveal the result of the path analysis. We used bootstrapping approach to observe data set to evaluate significant of path coefficient (t-value) and we also figured out $(\beta)$ value to observe path coefficient value. Figure 1 and Table 4 show the path coefficients and significant level for the research model. The result in Table 3 also shows that two independent variables have significant impact on intention to Waqf (promotion and knowledge). The result of the path analysis is presented in Table 4. The result of $\mathrm{H} 1$ reveals that knowledge is significantly related to Cash Waqf awareness $(\beta=0.474, p<0.01)$, and H2 reveals significant to cash waqf awareness $(\beta=-0.433, p<0.05)$. The structural model predicted $50 \%$ of the variance explained with positive impact on cash waqf awareness. Discussion will be given based on the new finding later.

\section{Conclusion}

Raising awareness on cash wakaf is very important as there are still many Muslims who hold to the idea that wakaf is only in permanent property. Every factor that has been studied shows that it is important in influencing the level of awareness of the Muslim community. The results of the study found that the factors of promotion and knowledge are significant and positively related in providing awareness and understanding of cash endowment. This shows that certain communities in the Pahang region have a good perception of cash waqf. The aspect of promotion and knowledge about cash waqf is very important in raising awareness of Cash 
waqf. The lack of promotion is likely to explain Malaysia's low awareness of Waqf. This claim is clearly backed by recent studies such as (Faiz ,2014; Ibrahim et al. 2013). He pointed out that a failure to promote waqf contributions and practises can have a huge impact, respectively, on the need to raise awareness of Cash Waqf's socio-economic potential as an Islamic social financing option (Adeyami, Ismail \& Hassan, 2016). In addition, numerous closely linked studies show that these marketing and promotional tools have been used positively and substantially in charitable donations. Mano (2013) found for example, in his study, the significant impact on voluntary involvement and financial contribution among residents of the United States of America by social media and network. This indicates that the promotional factor has a very large impact on the awareness of a matter and issue.

Apart from that, the knowledge factor also plays a role in increasing the understanding of this cash waqf. Based on the findings of this study, this factor contributes significantly to awareness among the people of Pahang region. Previous research shows that people with more knowledge are more confident in taking proper choices and less interested in other people's information and opinions (Clark \& Goldsmith, 2006; Shukor, Anwar, Aziz \& Sabri, 2017). Thus, it is believed that widespread knowledge of waqf, especially cash waqf, could promote endowments. From these two perspectives, this study proves that these findings confirm previous findings are relevant. promotional factors and knowledge play a role in giving the community an understanding of waqf cash. Therefore, this study is expected to help the parties involved, especially MUIPS in raising awareness of the local community in order to increase involvement in the cash endowment activities that can be participated by all levels of society.

\section{References}

Adeyemi, A. A., Ismail, N. A., \& Hassan, S. S. B. (2016). An empirical investigation of the determinants of cash Waqf awareness in Malaysia. Intellectual Discourse, 24, 501-520.

Anderson, J. C., \& Gerbing, D. W. (1988). Structural equation modeling in practice: A review and recommended two-step approach. Psychological Bulletin, 103(3), 411-423.

Adeyemi, A., Ismail, N., \& Hassan, S. S. (2016). An Empirical Investigation of the

Determinants of Cash Waqf Awareness in Malaysia. Intellectual Discourse, 24. from http://journals.iium.edu.my/intdiscourse/index.php/islam/article/view/931

Davidsson, B., \& Patel, R. (2003). Forskningsmetodikensgrunder. Lun: Studentlitteratur.

Faiz, O. A. (2014). An Analysis of Cash Waqf Participation among Young Intellectuals. 13 April 2014, Istanbul 9th International Academic Conference

Sekaran, U. (2003). Research and Markets: Research Methods for Business - A Skill Building Approach. In John Wiley \& Sons.

Shukor, S. A., Anwar, I. F., Aziz, S. A., \& Sabri, H. (2017). Muslim attitude towards participation in cash WAQF: Antecedents and consequences. International Journal of Business and Society, 18(S1), 193-204.

Cain, M. K., Zhang, Z., \& Yuan, K. H. (2016). Univariate and multivariate skewness and kurtosis for measuring nonnormality: Prevalence, influence and estimation. Behavior Research Methods, 49(5), 1716-1735.

Chin, W. W., Marcolin, B. L., \& Newsted, P. R. (2003). A partial least squares latent variable modeling approach for measuring interaction effects: results from a monte carlo simulation study and an electronic-mail emotion adoption study. Information Systems Research, 14(2), 189-217. 
Franke, G., \& Sarstedt, M. (2019). Heuristics versus statistics in discriminant validity testing: a comparison of four procedures. Internet Research, 29(3), 430-447.

Hahn, E. D., \& Ang, S. H. (2017). From the editors: New directions in the reporting of statistical results in the Journal of World Business. Journal of World Business, 52(2), 125-126.

Hair, J. F., Thomas, G., Hult, M., Ringle, C. M., \& Sarstedt, M. (2017). A Primer on Partial Least Squares Structural Equation Modeling ( 2 nd ed.). Thousand Oakes, CA: Sage.

Hair, J., Risher, J., Sarstedt, M., \& Ringle, C. (2019), When to use and how to report the results of PLS-SEM. European Business Review, 31(1), 2-24.

Henseler, J., Ringle, C., \& Sarstedt, M. (2015). A New Criterion for Assessing Discriminant Validity in Variance-based Structural Equation Modeling. Journal of the Academy of Marketing Science, 43(1), 115-135.

Kock, N. (2015). Common method bias in PLS-SEM: A full collinearity assessment approach. International Journal of e-Collaboration, 11(4), 1-10.

Kock, N., \& Lynn, G. S. (2012). Lateral collinearity and misleading results in variance-based SEM: An illustration and recommendations. Journal of the Association for Information Systems, 13(7), 546-580.

Lekvall, P., \& Wahlbin, C. (2001). Information för marknadsföringsbeslut. IHM publishing.

Mano, R. S. (2013). Social Media, social causes, giving behavior and money contributions. Computers in Human Behavior. Volume 31. Pg 287-293

Ramayah, T., Cheah, J., Chuah, F., Ting, H., \& Memon, M. A. (2018). Partial Least Squares Structural Equation Modeling (PLS-SEM) using SmartPLS 3.0: An Updated Guide and Practical Guide to Statistical Analysis (2nd ed.). Kuala Lumpur, Malaysia: Pearson.

Ringle, C. M., Wende, S., \& Becker, J.-M. (2015). "SmartPLS 3." Boenningstedt: SmartPLS $\mathrm{GmbH}$, http://www.smartpls.com

Sekaran, U., \& Bougie, R. (2010). Research Methods for Business. New York: John Wiley \& Sons Ltd.

Shmueli, G., Ray, S., Velasquez Estrada, J. M., \& Chatla, S. B. (2016). The Elephant in the Room: Predictive Performance of PLS Models. Journal of Business Research, 69(10), 45524564.

Shmueli, G., Sarstedt, M., Hair, J. F., Cheah, J. H., Ting, H., Vaithilingam, S., \& Ringle, C. M. (2019). Predictive Model Assessment in PLS-SEM: Guidelines for Using PLSpredict. European Journal of Marketing, 53(11), 2322-2347. 